Original Research Paper

\title{
Distribution and Diversity of Echinoderms in the Coastal Waters of South Beach of Lombok Island
}

\author{
Syamsul Bahri ${ }^{1,2}$, Lalu Raftha Patech ${ }^{1 *}$, Zulhalifah $^{1}$, Devi Ayu Septiani ${ }^{1}$, Siswadi $^{1}$ \\ ${ }^{1}$ Departement of Sciences Education Postgraduate Mataram University, Indonesia \\ ${ }^{2}$ Departement of Biological Sciences Education, Faculty of Teacher Training and Education, Mataram University, \\ Indonesia
}

\author{
Article History \\ Received : December $29^{\text {th }}, 2020$ \\ Revised : January $01^{\text {th }}, 2021$ \\ Accepted : January $05^{\text {th }}, 2021$ \\ Published : January $10^{\text {th }}, 2021$ \\ *Corresponding Author: \\ Lalu Raftha Patech, \\ Departement of Sciences Education \\ Postgraduate Mataram University, \\ Indonesia \\ Email: \\ laluraftapateh31@gmail.com
}

\begin{abstract}
Echinoderms are benthic animals that can be found in almost all marine ecosystems but are mostly found in the intertidal coastal zone. Echinoderms play an important role as deposit feeders. This study aims to look at the distribution patterns, diversity, and habitat conditions of species in the southern coastal waters of Lombok Island, namely Kute, Awang, and Gerupuk beaches. The field survey was conducted using the quadratic transect method and free collection in October - November 2020. Based on the results of the research, a total of 11 species of echinoderms were found in Lombok Island consisting of 4 classes. Diadema setosum and Tripneusteus gratila were the most common species, whereas Synapta maculate, Holothuria leucospilota, Echinotrix diadema, Holothuria atra, and Ophiocoma scolopendrina were found in small numbers with uniform distribution ( $\mathrm{Id}<1)$. Diadema setosum distribution pattern has the highest abundance with a clustered distribution pattern (Id>1) in Awang and Gerupuk, and Tripneusteus gratila in Kute and Awang. The Diversity Index value is different in each habitat. The highest Shannon-Wiener Diversity Index $\left(\mathrm{H}^{\prime}\right)$ was found in Gerupuk 2.18. The largest smoothing index is found at Awang 0.96. The largest Dominance Index (D) is found in Gerupuk 0.88 . Based on the value of the Echinoderm community structure on the South Coast of Lombok Island, it shows that diversity is moderate, community uniformity is unstable, and dominance is low. information regarding the distribution and diversity of Echinoderm fauna in various types of habitats around the seagrass as a first step to anticipate the decline in the Echinoderm population in the waters of the South Coast of Lombok Island.
\end{abstract}

Keywords: Distribution; diversity; echinoderms; habitat.

\section{Pendahuluan}

Echinodermata berasal dari bahasa Yunani Echinos artinya duri, dan derma artinya kulit. Secara umum echinodermata berarti hewan yang berkulit duri. Echinodermata terbagi atas 5 kelas yaitu kelas Asteroidea, Echinoidea, Holothuroidea, Ophiuroidea dan Crinoidea. Hewan ini memiliki kemampuan anatomi serta regenerasi bagian tubuh yang hilang, putus atau rusak (Jasin, 1984). Habitat echinodermata dapat ditemukan hampir pada semua ekosistem laut, namun paling banyak ditemukan pada zona pantai intertidal yang ditumbuhi oleh padang lamun.

Keberadaan echinodermata pada padang lamun sebagai habitat kompleks dan sangat penting bahkan bagi spesies lain seperti bivalvia, crustacea, cephalopoda, siput, dan ikan (Lowery,
J.L. et al., 2007). Echinodermata disebut sebagai kunci ekologi yang berperan dalam menjaga keseimbangan ekosistem laut, termasuk ekosistem lamun yang merupakan salah satu habitat bagi echinodermata (Raghunathan \& Venkataraman, 2012). Secara ekologi echinodermata berperan sangat penting di ekosistem lamun, terutama dalam rantai makanan (food web) (Hermosillo-Núñez, B. B., 2020). Echinodermata adalah spesies yang mencolok di ekosistem pesisir dan laut, dan dalam banyak kasus, mereka memiliki peran ekologis dalam struktur komunitas, bertindak sebagai predator teratas dan pemakan bentik (Ortiz \& Levins, 2011; Steneck et al., 2002). Selain itu, mereka berkontribusi pada proses bioerosion, rekrutmen dan transfer energi di ekosistem laut (Bronstein \& Loya, 2014), dan beberapa di antaranya 
sebagai sumber daya yang penting secara ekonomi (Claoue' et al., 1988).

Padang lamun sebagai ekosistem memiliki fungsi ekologi diantaranya adalah pertama sumber keranekaraman genetik yang memiliki pengaruh yang besar terhadap produktivitas dan stabilitas ekosistem, kedua adalah fungsi kontrol pada konsumen pada sistem tropik, dan ketiga membantu pergerakan aktif konsumen di antara habitat yang berdekatan dalam hal siklus nutrisi, transfer tropik, produksi perikanan, dan keanekaragaman spesies contohnya pada keanekaragaman echinodermata sebagai biota yang hidup di sekitar lamun (Syukur, 2015; Duffy, 2006). Di Pulau Lombok Potensi ekologi lamun nya diduga telah mengalami degradasi dari beberapa indikator organisme asosiasinya seperti ikan, moluska, kepiting, sea-urchin, dan echinodermata yang sudah sangat sulit ditemukan (Syukur et al., 2017). Degradasi Lamun diduga karena Meningkatnya aktivitas nelayan lokal dan tradisi madak di sekitar pesisir pantai selatan Pulau Lombok menjadi penyebab menurunnya populasi echinodermata. Eksploitasi yang semakin intensif juga dikhawatirkan akan mengancam kelestarian fauna tersebut.

Disatu sisi, aktivitas perburuan biota echinodermata memberikan dampak positif terhadap peningkatan nilai gizi dan ekonomi masyarakat pesisir Pulau Lombok. Disisi lain, penangkapan yang semakin intensif memberikan dampak negatif terhadap ekosistem. Fauna echinodermata memegang peranan penting dalam ekosistem lamun dan terumbu karang. Apabila penangkapan terus meningkat dikhawatirkan memberikan perubahan besar dalam susunan komunitas fauna dan pada akhirnya akan mengganggu keseimbangan ekosistem (Syukur, 2013).

Informasi mengenai Distribusi dan Keragaman fauna echinodermata di Pulau Lombok khususnya di sekitaran pantai Pesisir Selatan Pulau Lombok yakni Pantai Kute, Awang, dan Gerupuk belum pernah dilaporkan. Beberapa informasi yang ada adalah di perairan Lombok Barat bagian selatan (Aziz \& Sugiarto, 1994), Lombok Barat bagian utara (Aziz, 1995), Sekotong (Yusron, 2003) dan beberapa lokasi di perairan selatan Lombok Timur (Patech et al., 2020). Penelitian ini bertujuan untuk melengkapi informasi mengenai distribusi dan keragaman fauna echinodermata pada berbagai tipe habitat di sekitar lamun sebagai langkah awal mengantisipasi penurunan populasi echinodermata di perairan pantai selatan Pulau Lombok.

\section{Bahan dan Metode}

\section{Waktu dan Lokasi}

Penelitian ini dilakukan pada bulan Oktober sampai November 2020. Lokasi penelitian ini yakni di Pantai Kute, Awang, dan Gerupuk. Lokasi penelitian adalah daerah tangkapan nelayan tradisional, dan masyarakat yang melakukan aktivitas pengambilan secara langsung biota laut yang bernilai ekonomis dan sebagai konsumsi "madak", serta dimanfaatkan sebagai objek wisata alam pantai dan budidaya laut (Syukur \& Mahrus, 2016; Syukur et al., 2020). Lokasi penelitian adalah wilayah pesisir selatan Pulau Lombok (Gambar 1).

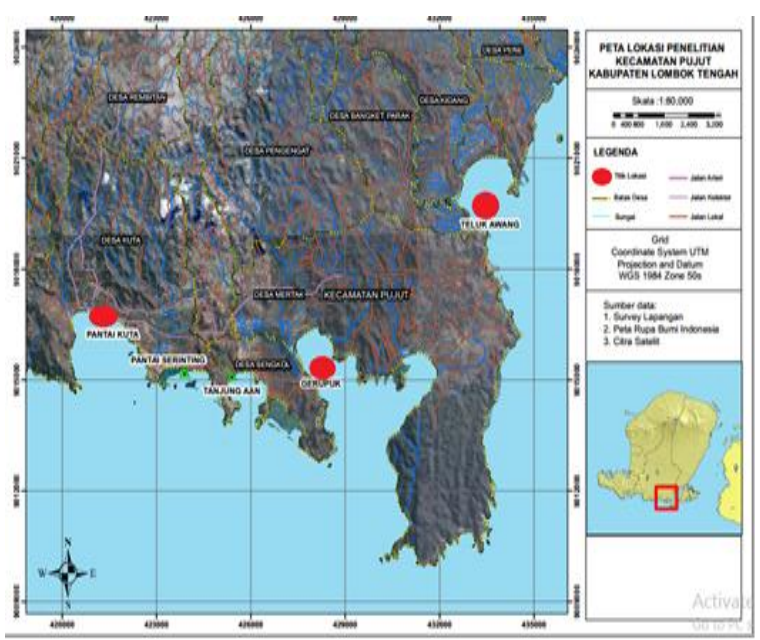

Gambar 1. Lokasi Penelitian

Pengambilan data dilakukan pada saat air laut surut terendah menggunakan metode gabungan antara transek garis dan kuadrat berukuran 1 x $1 \mathrm{~m}^{2}$. Jarak antar tiap kuadrat pada garis transek adalah 10 meter. Pengambilan sampel pada setiap kuadrat dilakukan dengan cara koleksi bebas (Free collection). Identifikasi sampel berpedoman pada buku Monograph of Shallow Water Indo-West Pacific Echinoderms (Clark \& Rowe, 1971) serta laporan hasil penelitian-penelitian yang relevan. Semua sampel difoto untuk didokumentasikan. Kemudian dilakukan pula analisis statistik untuk menghitung kelimpahan echinodermata, dan formula dari Odum (1993) untuk Indeks keanekaragaman spesies dihitung berdasarkan rumus Shannon \& Wiener. Indeks Keseragaman dengan rumus Evenness, dan Indeks Dominansi dengan rumus Simpsons.

Analisis Data 


\section{Distribusi Echinodermata}

Distribusi atau Pola penyebaran Echinodermata ditentukan dengan menghitung indeks dispersi Morisita (Id) dengan persamaan:

Keterangan:

$$
\operatorname{Id}=\frac{n\left(\sum_{i=1}^{5} x^{2}-N\right)}{N(N-1)}
$$

Id = Indeks dispersi Morisita

$\mathrm{n} \quad=$ Jumlah plot pengambilan contoh

$\mathrm{N}=$ Jumlah individu dalam plot

$\mathrm{X}=$ Jumlah individu pada setiap plot

Pola dispersi Echinodermata ditentukan dengan menggunakan kriteria sebagai berikut (Akhrianti, 2014):

Id $<1$ : Pola dispersi seragam

$\mathrm{Id}=1$ : Pola dispersi acak

Id > 1: Pola dispersi mengelompok

\section{Indeks keragaman spesies}

\section{Keanekaragaman Echinodermata}

Indeks keanekaragaman spesies dihitung berdasarkan rumus Shannon \& Wiener (Akhrianti, 2014):

$$
\begin{aligned}
\mathrm{H}^{\prime} & =-\sum_{\mathrm{Pi}} \mathrm{Pi} \ln \mathrm{Pi} \\
\mathrm{Pi} & =\frac{n i}{N}
\end{aligned}
$$

Keterangan:

$$
\begin{aligned}
\mathrm{H}^{\prime} & =\text { Indeks keanekaragaman jenis } \\
\mathrm{ni} & =\text { Jumlah individu dari speies ke- } i \\
\mathrm{~N} & =\text { Jumlah individu total } \\
\mathrm{Pi} & =\text { ni/ } \mathrm{N}
\end{aligned}
$$

\section{Keseragaman Echinodermata}

Analisis berikutnya adalah kesamaan distribusi individu dari setiap spesies Echinoderms, di bagian ini menggunakan analisis indeks Evenness, dengan rumus:

Keterangan:

$$
E=\frac{H^{\prime \prime}}{H_{\max }}
$$

$\mathrm{E} \quad=$ Indeks Evenness

$\mathrm{H}^{\prime} \quad$ = Nilai indeks keanekaragaman

$\mathrm{H}_{\max }=$ Nilai indeks keanekaragaman maksimal

\section{Dominansi Echinodermata}

Indeks dominansi dihitung dengan menggunakan indeks dominansi Simpson dengan rumus:

$$
D=1-\frac{\sum n i(n i-1)}{N(N-1)}
$$

Keterangan:

$\mathrm{D}=$ Indeks Dominansi

$n i=$ Jumlah individu jenis- $i$

$\mathrm{N}=$ Jumlah total individu

\section{Kondisi Lingkungan}

Analisis data lingkungan pada tiga lokasi penelitian dilakukan pada tiap-tiap stasiun pengamatan secara langsung (insitu). Parameter lingkungan yang diukur adalah substrat, $\mathrm{pH}$, suhu,dan salinitas.

\section{Hasil dan Pembahasan}

\section{Jenis Echinodermata}

Hasil penelitian di Pesisir Pantai Selatan diperoleh 11 jenis spesies dari filum echinodermata yang terdiri dari 4 kelas seperti disajikan pada Tabel 1. Spesies Diadema setosum dan Tripneusteus gratila adalah spesies yang paling banyak ditemukan dan spesies Synapta maculate, Holothuria leucospilota, Echinotrix diadema, Holothuria atra, dan Ophiocoma scolopendrina adalah spesies yang rata-rata paling sedikit ditemukan di semua lokasi studi. Jumlah spesies echinodermata di lokasi studi lebih rendah dari jumlah spesies echinodermata yaitu 29 spesies pada padang lamun di Perairan Sekotong, Lombok Barat (Yusron, 2003), di Perairan Tanjung Merah 21 spesies Echinodermata (Yusron \& Susetiono, 2005), dan di Perairan Pesisir Pantai Selatan Lombok Timur 14 Spesies (Patech et al., 2020). Namun demikian lebih tinggi dengan Babanlagan Filipina yang hanya 10 spesies echinodermata (Llacuna et al., 2016). 
Tabel 1. Jenis Echinodermata yang ditemukan di Pesisir Pantai Selatan

\begin{tabular}{|c|c|c|c|c|c|}
\hline No & Lokasi & Class & Family & Spesies & $\begin{array}{l}\text { Jumlah } \\
\text { Individu }\end{array}$ \\
\hline \multirow{9}{*}{1} & \multirow{9}{*}{ Kute } & \multirow{2}{*}{ Asteroidea } & Oreasteridae & o Protoreaster nodosus & 61 \\
\hline & & & Archasteridae & o Archaster typicus & 35 \\
\hline & & \multirow{4}{*}{ Echinoidea } & Toxopneustidae & o Tripneusteus gratila & 119 \\
\hline & & & Temnopleuridae & o Mespilia globulus & 75 \\
\hline & & & Diadematidae & o Diadema calamaris & 58 \\
\hline & & & Diadematidae & o Diadema setosum & 90 \\
\hline & & \multirow{3}{*}{ Holothuroidea } & Synaptidae & $o \quad$ Synapta maculate & 50 \\
\hline & & & Holothuriidae & o Holothuria leucospilota & 15 \\
\hline & & & Holothuriidae & o Holothuria atra & 19 \\
\hline \multirow{5}{*}{2} & \multirow{5}{*}{ Awang } & Asteroidea & Archasteridae & o Archaster typicus & 61 \\
\hline & & \multirow{2}{*}{ Echinoidea } & Diadematidae & o Diadema setosum & 65 \\
\hline & & & Toxopneustidae & o Tripneusteus gratila & 77 \\
\hline & & \multirow{2}{*}{ Holothuroidea } & Synaptidae & o Synapta maculate & 40 \\
\hline & & & Holothuroiidea & o Holothuria leucospilota & 27 \\
\hline \multirow{10}{*}{3} & \multirow{10}{*}{ Gerupuk } & Asteroidea & Oreasteridae & o $\quad$ Protoreaster nodosus & 50 \\
\hline & & & Toxopneustidae & o Tripneusteus gratila & 73 \\
\hline & & & Diadematidae & o Diadema calamaris & 56 \\
\hline & & Echinoidea & Diadematidae & o Diadema setosum & 99 \\
\hline & & & Diadematidae & $o \quad$ Echinotrix diadema & 63 \\
\hline & & & Temnopleuridae & o Mespilia globulus & 45 \\
\hline & & & Synaptidae & o Synapta maculate & 35 \\
\hline & & Holothuroidea & Holothuriidae & o Holothuria atra & 33 \\
\hline & & & Holothuriidae & o Holothuria leucospilota & 25 \\
\hline & & Ophiuroidea & Ophiocomidae & o Ophiocoma scolopendrina & 11 \\
\hline
\end{tabular}

\section{Distribusi (Id) Echinodermata di lokasi studi}

Pola penyebaran menggambarkan distribusi Echinodermata yang dikelompokkan ke dalam penyebaran seragam $(\mathrm{Id}<1)$ dan mengelompok (Id $>1)$. Seperti terlihat pada tabel 2. Nilai Indeks Dispersi Morisita menunjukkan bahwa spesies Tripneusteus gratila di Pantai Kute memiliki pola sebaran mengelompok. Selanjutnya spesies Tripneusteus gratila, Archaster typicus, dan Diadema setosum di Pantai Awang dengan pola sebaran mengelompok dan Pantai Gerupuk lebih banyak dengan pola penyebaran seragam kecuali spesies Diadema setosum. Perbedaan pola penyebaran ditentukan oleh jumlah populasi dari tiap spesies selama periode pengambilan data, dan pola sebaran mengelompok karena jumlah populasi dari tiap spesies ditemukan dalam jumlah yang lebih banyak. Spesies echinodermata Diadema Setosum dan Tripneusteus gratila memiliki pola sebaran mengelompok, hal ini disebabkan karena spesies echinodermata tersebut dapat ditemukan pada tipe substrat yang lebih beragam sebagai habitatnya. Dalam hal ini, Diadema setosum dan beberapa spesies lain seperti Tripneustes gratilla dapat ditemukan mulai dari rataan pasir, padang lamun, rataan karang dan tubir, hingga ke daerah bebatuan (Budiman et al., 2014; Firmandana, 2014). 
Tabel 2. Pola sebaran Echinodermata di lamun pesisir Pantai Selatan

\begin{tabular}{clccc}
\hline \multirow{2}{*}{ No } & \multicolumn{2}{c}{ Jenis Echinodermata } & \multicolumn{3}{c}{ Id (Lokasi) } \\
\cline { 3 - 5 } & & Kute & Awang & Gerupuk \\
\hline 1 & Protoreaster nodosus & 0,35 & - & 0,25 \\
2 & Archaster typicus & 0,08 & 1,43 & - \\
3 & Diadema calamaris & 0,31 & - & 0,33 \\
4 & Mespilia globulus & 0,56 & - & 0,19 \\
5 & Tripneusteus gratila & 1,50 & 2,34 & 0,61 \\
6 & Diadema setosum & 0,84 & 1,63 & 1,17 \\
7 & Synapta maculate & 0,22 & 0,55 & 0,09 \\
8 & Holothuria leucospilota & $-0,03$ & 0,19 & 0,02 \\
9 & Holothuria atra & $-0,02$ & - & 0,07 \\
10 & Echinotrix diadema & - & - & 0,44 \\
11 & Ophiocoma scolopendrina & - & - & $-0,05$ \\
\hline
\end{tabular}

Komposisi echinodermata yang paling mendominasi di ketiga lokasi studi adalah Diadema setosum. Hal ini menjelaskan ketergantungan yang sangat tinggi dari spesies Diadema setosum terhadap lamun sebagai makanan primer (Leaf eater on Seagrass). Pola penyebaran seragam ditemukan pada ketiga lokasi penelitian pada spesies Protoreaster nodosus, Diadema calamaris, Mespilia globulus, Synapta maculate, Holothuria leucospilota, Holothuria atra, Echinotrix diadema, dan Ophiocoma scolopendrina. Hal ini dapat dijelaskan karena jenis tersebut memiliki kebiasan hidup tidak berkelompok. Dalam hal ini Budiman et al., (2014) menyatakan spesies

\section{Indeks Ekologi Echinodermata}

Indeks keanekaragaman (H') di Kute dan Gerupuk tergolong sedang, sedangkan Keanekaragaman (H') di Awang tergolong Rendah. Indeks keseragaman di ketiga Lokasi Penelitian (E) tergolong stabil dan indeks dominansi (D) tergolong tinggi. Semakin tinggi
Amphiura sp., Centrostephanus rodgersii. Echinothrix diadema. Mespilia globules. Echinothrix mathei dan Pseudoboletia maculates lebih sering ditemukan tidak berkelompok atau terpisah dalam individu yang sedikit sebagai pertahanan diri dari musuh dan pemangsa. Selain itu, keberadaan spesies echinodermata pada semua lokasi studi dapat menggambarkan fungsi ekologi lamun. Dalam hal ini lamun dapat berperan sebagai habitat biota (Riniatsih, 2016). Selanjutnya, kehadiran spesies echinodermata dapat berfungsi dalam proses oksigenisasi lapisan atas sedimen untuk pertumbuhan lamun dan membantu mengontrol populasi hama dan bakteri-bakteri patogen (Wulandari et al., 2012).

nilai $\mathrm{H}^{\prime}$ maka semakin tinggi variasi spesies pada suatu wilayah. Indeks keanekaragaman sangat dipengaruhi oleh jumlah spesies dan individu (Odum, 1993). Ketiga nilai indeks tersebut disajikan pada Gambar 2. 


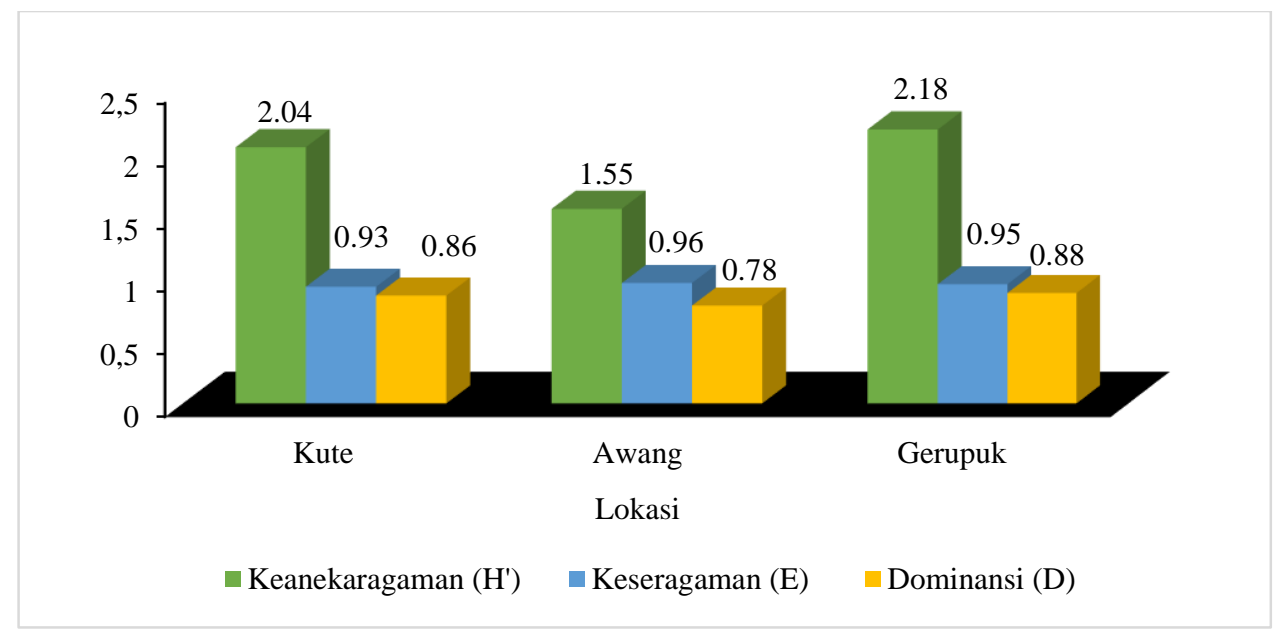

Gambar 2. Nilai indeks keanekaragaman (H'), keseragaman (E), dan dominansi (D) Echinodermata yang ditemukan di Pesisir Pantai Selatan

Berdasarkan perhitungan indeks keanekaragaman (H') yang telah dilakukan diperoleh keanekaragaman tertinggi terdapat di Pantai Gerupuk dengan nilai 2.18, Kute 2.04 dan yang terendah di Awang dengan nilai keanekaragaman 1.55 sehingga tergolong sedang. Berbeda dengan yang dilaporkan Patech et al., (2020) di Perairan Pesisir Pantai Selatan Lombok Timur rata-rata Keanekaragaman Echinodermata yakni 1.48 yang tergolong rendah. Indeks keseragaman (E) tertinggi di Pantai Awang dengan nilai 0.96 sehingga tergolong kategori tinggi. Indeks dominansi relatif diperoleh dominansi tertinggi di Pantai Gerupuk dengan nilai 0.88 yang tergolong kategori tinggi yang berarti ada jenis yang mendominasi seperti Tripneusteus gratila, Echinotrix diadema, dan Diadema setosum.

Faktor yang menentukan tinggi rendahnya keanekaragaman spesies pada suatu lokasi antara lain dipengaruhi oleh kondisi fisik lingkungan. Nilai indeks keanekaragaman echinodermata pada ketiga lokasi penelitian tidak jauh berbeda, salah satunya disebabkan oleh variasi substrat dasar perairan. Nilai indeks Keseragaman (E) menunjukkan pola sebaran individu pada suatu lokasi. Jika indeks keseragamannya semakin besar maka pola sebaran individu pada suatu lokasi merata, sebaliknya jika nilai indeks keseragamannya semakin kecil menujukkan pola sebaran individu yang tidak merata. Nilai indeks keseragaman yang diperoleh di lokasi penelitian adalah berkisar antara $0.93-0.96$ dan termasuk dalam kategori stabil. Nilai indeks keseragaman yang diperoleh dari ketiga lokasi penelitian menunjukkan bahwa pola sebaran spesies pada lokasi penelitian cukup merata yang menunjukkan bahwa komunitas pada kondisi stabil.

Berdasarkan hasil pengolahan data Indeks Dominansi (D) diperoleh nilai tertinggi di Pantai Gerupuk dengan nilai 0.88 yang tergolong kategori tinggi yang berarti ada jenis yang mendominasi. Apabila indeks dominansi relatif mendekati 1 berarti ada salah satu spesies yang mendominasi dan biasanya diikuti dengan indeks keaneakaragaman rendah begitu juga sebaliknya (Lina \& Zulfikar, 2015). Tingginya indeks dominansi echinodermata di ketiga lokasi penelitian berkaitan dengan nilai indeks keanekaragaman $\left(\mathrm{H}^{\prime}\right)$ dan indeks keseragaman (E). Odum (1993) menjelaksan nilai $\mathrm{H}^{\prime}$ dan $\mathrm{E}$ bersifat berbanding terbalik terhadap nilai D. Jika nilai $\mathrm{H}^{\prime}$ dan $\mathrm{E}$ tinggi maka nilai $\mathrm{D}$ akan rendah, sebaliknya jika nilai D tinggi maka nilai $\mathrm{H}^{\prime}$ dan E akan rendah. Nilai indeks dominansi Simpson (D) echinodermata di ketiga lokasi penelitian termasuk dalam kategori tinggi. Nilai tersebut menunjukkan bahwa adanya dominansi suatu jenis dalam ekosistem. Nilai indeks dominansi yang mendekati 1 menunjukkan adanya spesies yang mendominansi spesies lainnya. Sedangkan nilai indeks dominansi yang mendekati 0 menunjukkan hampir tidak ada dominansi dari suatu spesies dalam komunitas (Smith \& Smith, 2011). Perbedaan dari Teori Indeks Ekologis ini disebabkan oleh Perburuan yang dilakukan dari tradisi "madak" masyarakat sekitar pantai dan dari pengaruh kunjungan wisatawan, sehingga jumlah individu yang didapatkan jauh lebih sedikit sehingga mempengaruhi perhitungan indeks ekologis. 


\section{Parameter Lingkungan}

Pengukuran parameter lingkungan dilakukan pada setiap stasiun pengamatan yaitu di Pantai Kute, Awang, dan Gerupuk. Parameter lingkungan yang diamati adalah suhu, salinitas,
$\mathrm{pH}$, dan substrat dari lingkungan lamun tersebut secara in situ. Hasil pengukuran dari semua parameter menunjukkan nilai yang masih layak untuk kelangsungan hidup organisme air (Tabel $3)$.

Tabel 3. Hasil pengukuran faktor lingkungan pada lokasi studi

\begin{tabular}{llcccl}
\hline \multirow{2}{*}{ No } & \multirow{2}{*}{ Lokasi } & \multicolumn{3}{c}{ Parameter lingkungan } \\
\cline { 3 - 6 } & & Suhu & Salinitas & $\mathrm{pH}$ & \multicolumn{1}{c}{ Substrat } \\
\hline 1 & Kute & $27,00 \pm 1,55$ & $34,43 \pm 1,40$ & $7,18 \pm 0,25$ & Berpasir \& pecahan karang \\
2 & Awang & $26,76 \pm 2,00$ & $34,62 \pm 0,93$ & $7,43 \pm 0,17$ & Lumpur berpasir \\
3 & Gerupuk & $26,00 \pm 1,26$ & $31,36 \pm 4,80$ & $7,00 \pm 0,01$ & Berpasir \& pecahan karang \\
\hline
\end{tabular}

Nilai dari tiap parameter lingkungan mendukung pertumbuhan echinodermata. sesuai baku mutu Kepmenneg LH No.51 tahun 2004. Rentangan suhu di Pantai Kute 27,00 $\pm 1,55$, Awang 26,76 $\pm 2,00$, dan Gerupuk 26,00 $\pm 1,26$. Aziz (1988) melaporkan bahwa bulu babi dari famili Diadematidae dan Toxopneustidae akan mengalami kematian pada suhu $36-40^{\circ} \mathrm{C}$ dan bintang mengular dari famili Ophiocomidae, Ohionereidae, dan Amphiuridae mengalami kematian pada suhu $39-40^{\circ} \mathrm{C}$.

Salinitas adalah salah satu parameter lingkungan yang memiliki pengaruh signifikan terhadap keberadaan echinodermata. Namun demikian, Setiap spesies echinodermata memiliki toleransi yang tidak sama terhadap salinitas. Rata-rata memiliki toleransi terhadap salinitas antara 15-29 \%o dan nilai optimum salinitas untuk biota lamun dan terumbu karang adalah 33-35 \%o. Selanjutnya, belum ada publikasi tentang batas toleransi $\mathrm{pH}$ bagi fauna echinodermata, tetapi berdasarkan baku mutu Kepmenneg LH No.51 tahun 2004 kisaran pH alami untuk biota lamun dan terumbu karang adalah 7-8,5. Hutauruk (2009) menyatakan kondisi perairan yang sangat basa akan membahayakan organisme karena akan mengganggu metabolisme dan respirasi, dan perairan yang asam akan menyebabkan mobilitas berbagai senyawa logam berat terutama aluminium akan meracuni biota echinodermata.

Variasi substrat dasar perairan di ketiga lokasi studi memiliki variasi yang sama yakni bersubstrat lumpur berpasir, dan berpasir dengan pecahan karang. Variasi substrat yang sama antara ketiga lokasi penelitian menyebabkan jumlah individu masing-masing spesies echinodermata yang ditemukan tidak jauh berbeda, sehingga indeks keanekaragaman spesies pada ketiga lokasi penelitian tidak berbeda secara signifikan seperti yang ditemukan di Kute dan Gerupuk. Hal tersebut sesuai dengan Pancawati et al., (2014) yang menyatakan bahwa substrat dasar merupakan salah satu faktor yang dapat mempengaruhi penyebaran makrozobentos (echinodermata), karena selain berperan sebagai tempat tinggal juga berfungsi sebagai penimbun unsur hara (sebagai media penyedia sumber makanan), tempat berkumpulnya bahan organik serta tempat perlindungan organisme dari ancaman predator.

\section{Kesimpulan}

Hasil studi di Pesisir Pantai Selatan Pulau Lombok diperoleh 11 jenis spesies dari filum echinodermata. Selanjutnya, Diadema setosum dan Tripneusteus gratila adalah spesies yang paling banyak ditemukan di semua lokasi studi. Nilai Indeks Dispersi Morisita (Id) menunjukkan bahwa pola penyebaran mengelompok pada spesies Tripneusteus gratila di Pantai Kute, Archaster typicus, Tripneusteus gratila, Diadema setosum di Pantai Awang, sedangkan Diadema setosum di Pantai Gerupuk. Indeks keanekaragaman (H') tertinggi terdapat di Pantai Gerupuk dengan nilai 2.18, Kute 2.04 yang tergolong sedang, sedangkan di Awang dengan nilai keanekaragaman 1,55 sehingga tergolong rendah. Indeks keseragaman (E) tergolong stabil, dan indeks dominansi (D) tergolong tinggi di semua lokasi studi. Selanjutnya, parameter lingkungan menurut Kepmenneg LH Nomor 51 untuk baku mutu air laut dan biota asosiasinya menunjukkan nilai yang masih layak untuk kelangsungan hidup echinodermata. 


\section{Ucapan terima kasih}

Tim peneliti mengucapkan terima kasih kepada Magister Pendidikan IPA Pascasarjana Universitas Mataram yang memberikan dana penelitian dan pelatihan analisis data serta penulisan karya ilmiah, serta pihak lain yang berkontribusi secara signifikan.

\section{Referensi}

Akhrianti, I.D.G. (2014). Distribusi Spasial dan Preferensi Habitat Bivalvia di pesisir Perairan Kecamatan Simpang Pesak Kabupaten Belitung Timur. Jurnal Ilmu dan Kelautan Tropis. 6 (1): 171-185. https://doi.org/10.29244/jitkt.v6i1.8639

Aziz, A. (1995). Beberapa catatan mengenai fauna Ekhinodermata dari Lombok. Dalam: Pengembangan dan pemanfaatan potensi kelautan: potensi biota, teknik budidaya dan kualitas perairan. DP Praseno, WS Atmadja, I. Supangat, Ruyitno, dan BS Sudibjo (Eds). Pusat Penelitian dan Pengembangan Oseanologi-LIPI. Jakarta, 43-50.

Aziz, A. (1988). Pengaruh Tekanan Panas Fauna Echinodermata. Oseana 13 (3): 125-132. http://oseanografi.lipi.go.id/dokumen/ose ana_xiii(3)125-132.pdf

Aziz, A., \& Sugiarto, H. (1994). Fauna ekhinodermata padang lamun di Pantai Lombok Selatan. Jakarta. (ID): Puslitbang LIPI P2O.

Bronstein, O. \& Y. Loya, (2014). Echinoid community structure and rates of herbivory and bioerosion on exposed and sheltered reefs. Journal of Experimental Marine Biology and Ecology 456: 8-17. https://doi.org/10.1016/j.jembe.2014.03.0 03

Budiman, C.C., Maabuat, P.V., Langoy, M.L.D., \& Katili, D.Y. (2014). Keanekaragaman Echinodermata di Pantai Basaan Satu Kecamatan Ratatotok Sulawesi Utara. Jurnal Mipa Unsrat Online 3 (2): 97-101. https://doi.org/10.35799/jm.3.2.2014.585 9
Claoue', C., T. Hodges, T. Hill, W. Blyth \& D. Easty, (1988). Neural spread of herpes simplex virus to the eye of the mouse: microbiological aspects and effect on the blink reflex. Eye (Basingstoke) 2: 318323. https://doi.org/10.1038/eye.1988.60

Clark, A.M. and F. W. E. Rowe. (1971). Monograph of Shallow Water Indo-West Pacific Echinoderms. London, Trustees of British Museum: 171-210. https://ci.nii.ac.jp/naid/10029401934/

Duffy, J. E. (2006). Biodiversity and the functioning of seagrass ecosystems. Marine Ecology Progress Series, 311, 233-250. https://doi.org/10.3354/meps311233

Firmandana, T. C. (2014). Kelimpahan Bulu Babi (Sea Urchin) Pada Ekosistem Karang Dan Lamun Di Perairan Pantai Sundak, Yogyakarta. Management of Aquatic Resources Journal, 3 (4); 41-50. https://doi.org/10.14710/marj.v3i4.7030

Hermosillo-Núñez, B. B. (2020). Contribution of echinoderms to keystone species complexes and macroscopic properties in kelp forest ecosystems (northern Chile). Hydrobiologia, 847(3), 739-756. https://doi.org/10.1007/s10750-01904134-8

Hutauruk, E.L. (2009). Studi Keanekaragaman Echinodermata di Kawasan Kepulauan Rubiah Nanggro Aceh Darussalam. Skripsi. Universitas Sumatra Utara. http://repository.usu.ac.id/handle/123456 $789 / 13822$

Jasin, M. (1984). Sistematika hewan (invertebrata dan vertebrata). Surabaya: Sinar Wijaya), $h, \quad 159$. http://library.uny.ac.id/site/opacdetail?id= $\underline{18985}$

Keputusan Menteri Negara Lingkungan Hidup No. 51. (2004). Baku Mutu Air Laut. Jakarta: Kementrian Lingkungan Hidup. http://www.kelair.bppt.go.id/Hukum/data/ kepmen/bml/51-2004.pdf 
Lina, F. Lestari \& A. Zulfikar. (2015). Struktur Komunitas Gastropoda di Ekosistem mangrove Sungai Nyirih Kecamatan Tanjung Pinang Kota Tanjung Pinang. Jurnal Elektronik. 1-15. http://jurnal.umrah.ac.id/wpcontent/uploads/gravity_forms/1ec61c9cb232a03a96d0947c6478e 525e/20 16/07/Jurnal-Lina.pdf

Llacuna, M.E.J., Walag, A.M. \& Elaine A. Villaluz, E.A. (2016). Diversity and dispersion patterns of echinoderms in Babanlagan, Talisayan, Misamis Oriental, Philippines. Environmental and Experimental Biology 14 (1): 213-217. http://doi.org/10.22364/eeb.14.28

Lowery, J. L., Paynter Jr, K. T., Thomas, J., \& Nygard, J. (2007). The importance of habitat created by molluscan shellfish to managed species along the Atlantic Coast of the United States. Washington, DC: Atlantic States Marine Fisheries Commission.

https://www.researchgate.net/profile/Ray mond Grizzle2/publication/285046037 T he_importance_of_habitat_created_by_m olluscan_shellfish_to_managed_species_a long the_Atlantic_Coast_of the_United States/links/569000f008aee91f69a14239. pdf

Odum, E. P. (1993). Basics of Ecology Third Edition. Samingan, $\mathrm{T}$ (translator). Yogyakarta: Gadjah Mada University Press. p. 631-676. ISBN 9794202843

Ortiz, M. \& R. Levins, (2011). Re-stocking practices and illegal fishing in northern Chile (SE Pacific coast): a study case. Oikos 120: 1402-1412. https://doi.org/10.1111/j.1600-

0706.2011.19041.x

Pancawati, D.K., D. Suprapto, \& P.W. Purnomo. (2014). Karakteristik Fisika Kimia Perairan Habitat Bivalvia di Sungai Wiso Jepara. Diponegoro Journal of Marques, 3(4): 141-146. https://doi.org/10.14710/marj.v3i4.7048
Patech, L. R., Syukur, A., \& Santoso, D. (2020). Kelimpahan dan Keanekragaman Spesies Echinodermata sebagai Indikator Fungsi Ekologi Lamun di Perairan Pesisir Lombok Timur. Jurnal Sains Teknologi \& Lingkungan, $\quad 6(1), \quad$ 40-49. https://doi.org/10.29303/jstl.v6i1.148

Raghunathan. C, Venkataraman. K. (2012). Diversity of Echinoderms in Rani Jhansi. Journals of Marine National Park, Andaman and Nicobar Islands. International Day for Biodiversity. 1 (1) : 22-40.

http://www.upsbdb.org/pdf/Souvenir2012 lch-4.pdf

Riniatsih, I. (2016). Distribusi jenis lamun dihubungkan dengan sebaran nutrient perairan di padang lamun Teluk Awur Jepara. Jurnal Kelautan Tropis, 19 (2): $101-$ 107. https://doi.org/10.14710/jkt.v19i2.824

Smith, T.M., dan Smith, R.L. (2011). Elements of Ecology $8^{\text {th }}$ Edition. USA: Pearson Education. ISBN 9780321736079

Steneck, R. S., M. H. Graham, B. J. Bourque, D. Corbett, J. M. Erlandson, J. A. Estes \& M. J. Tegner, (2002). Kelp forest ecosystems: biodiversity, stability, resilience and future. Environmental Conservation 29: pp. 436-459. https://doi.org/10.1017/S0376892902000 322

Syukur, A., Al- Idrus, A., \& Zulkifli, L. (2020). Ecotourism development based on the diversity of echinoderms species in seagrass beds on the South. https://doi.org/10.3923/jest.2020.57.68

Syukur, A. (2013). Pengetahuan Ekologi Masyarakat Lokal sebagai Indikator Penilaian Potensi Lamun (Seagrass) di Tanjung Luar Lombok Timur. Jurnal Biologi Tropis, 13(2). http://dx.doi.org/10.29303/jbt.v13i2.153

Syukur, A. (2015). Distribusi, Keanekaragaman Jenis Lamun (Seagrass) dan Status Konservensinya di Pulau Lombok. Jurnal 
Biologi Tropis. 15 (2): 171-182. http://dx.doi.org/10.29303/jbt.v15i2.205

Syukur, A., \& Mahrus, SA (2016). The potential assessment environment friendly aquaculture of small- scale fishermen as a conservation strategy for seagrass beds in coastal areas of Tanjung Luar East Lombok, Indonesia. ISSN: 2347-5129 (ICV-Poland) Impact Value: 5.62 (GIF) Impact Factor: 0.352 IJFAS 2016; 4(2): 22-27

Syukur, A., Wardiatno, Y., Muchsin, I., \& Kamal, M. M. (2017). Threats to seagrass ecology and indicators of the importance of Seagrass ecological services in the coastal waters of East Lombok, Indonesia. American Journal of Environmental Sciences, 13 (3): 251-265. DOI: 10.3844/ajessp.2017.251.265

Wulandari, N., Krisanti, M., \& Elfidasari, D. (2012). Keragaman teripang asal Pulau Pramuka, Kepulauan Seribu Teluk Jakarta. Unnes Journal of Life Science, 1 (2); 133139.

http://journal.unnes.ac.id/sju/index.php/ Unnes J Life Sci. ISSN 2252-6277

Yusron, E. (2003). Beberapa Catatan Fauna Echinodermata di Perairan teluk Sekotong, Lombok Barat, Nusa Tenggara Barat. Prosiding Seminar Riptek Kelautan Nassional $1 \quad$ (2); 41-47. http://coremap.or.id/downloads/1002.pdf

Yusron, E. \& Susetiono (2005). Fauna Ekhinodermata dari Perairan Tanjung Merah Selat Lembeh - Sulawesi Utara. Makara Sains 9 (2); 60-65. https://doi/org/10.7454/mss.v9i2.53 